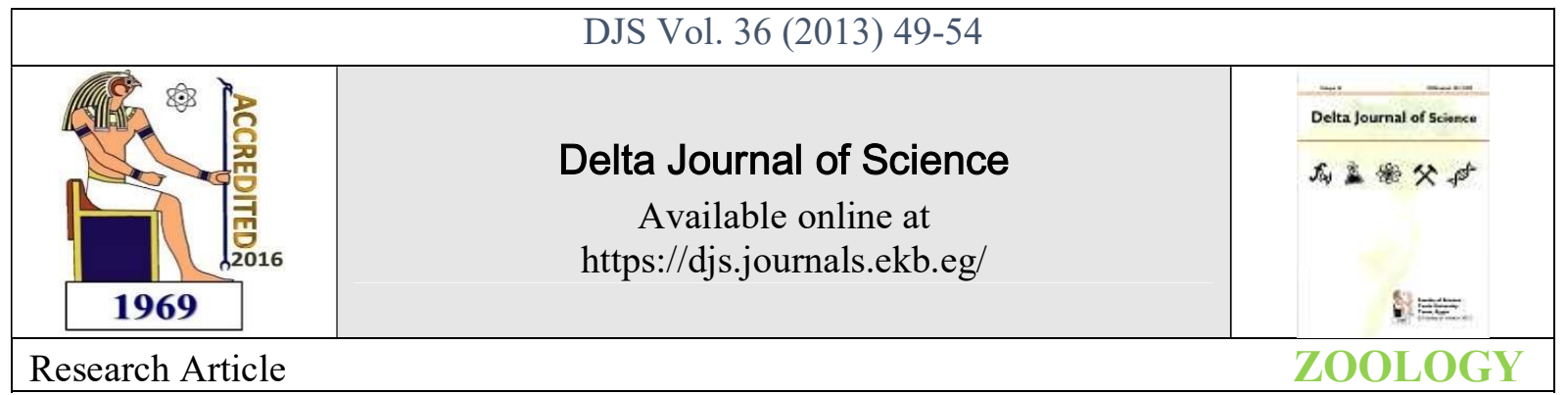

\title{
Interspecific variations of Biomphalaria alexandrina and Biomphalaria glabrata snails in the presence and absence of Schistosoma mansoni by using of protein profiles.
}

\author{
Wesam M. Salama \\ Tanta University, Faculty of Science, Zoology Department
}

\begin{abstract}
Schistosomiasis, the most important parasitic disease in Egypt, has plagued its people since ancient times. Two species of Biomphalaria are reported from Egypt, the indigenous Biomphalaria alexandrina and Biomphalaria glabrata, the latter is believed to be introduced during the past few decades. Both are known to be excellent hosts of Schistosoma mansoni, in Egypt. SDS-PAGE was used to separate tissue proteins of control and Schistosoma-infected Biomphalaria alexandrina and B.glabrata snails. Also total protein of these groups was measured using Bradford assay method. The present data showed that there is a variation in the protein profiles under the effect of infection, and the days of infections can also affect total and protein profiles pattern. There was a significant decrease in Balexandrina total protein, in contrary, total protein of B.glabrata groups exhibited significant and insignificant increase under the effect of infection. The electrophoretic pattern showed that there is an interspecific variation between B.alexandrina and B. glabrata control (non-infected) and infected ones. Protein profiles showed 13 bands ranged between 15-300 KDa, with a unique bands to some groups. The similarity indices showed the high value $(0.8)$ between the two Biomphalarian species.
\end{abstract}

This study is an attempt to specifiy characterization of similar species of animals using modern simple technique rather than morphological old methods, and further detects the variable protein bands due to infection with S.mansoni.

Keywords: Interspecific; Biomphalaria alexandrina ;Biomphalaria glabrata; protein profile.

\section{INTRODUCTION}

Parasitic platyhelminthic infections such as schistosomiasis affect humans in many countries of the western hemisphere, the pacific region, the Middle East, Asia and Africa. The reduction of transmission levels has been attempted in numerous ways, including mass chemotherapy and the application of molluscicides to restrict the spread of infection. It has long been recognized that control strategies aimed at the long term reduction of schistosomiasis cannot ignore the role of snails in its transmission. Preventing the spread of this disease in the long term has been difficult to sustain because of the tendency of snails for recolonization, the lack of surveillance of treated sites, extreme poverty, civil strife and the expansion of irrigation projects in high-risk regions of Sub-Saharan Africa and the Pacific Rim (Sturrock, 2001).

There are 34 described species of Biomphalaria snails, of which about 18 were known to be or presumed to be capable of supporting the complete larval development of Schistosoma mansoni (Malek, 1985; Brown, 1994). Two species of Biomphalaria were reported from Egypt, the indigenous Biomphalaria alexandrina and Biomphalaria glabrata, the latter is believed to be introduced during the past few decades, which is an ecologically successful and highly adapted member of the class Gastropoda (Hickman, 2000). Both snails are known to be excellent hosts of S.mansoni, the human infecting blood fluke common in Egypt.

In order to differentiate between B.glabrata and B.alexandrina in Egypt, Yousif et al. (1996) used shell morphology and morphometry, presence or absence of the renal ridges, and certain anatomical features of the pallial

cavity and radular teeth. While, Lotfy et al. (2005) and Bakry (2009) differentiate between B.glabrata and B.alexandrina using PCR assays based on nuclear sequences.

Snails like other invertebrates have efficient innate immune systems which is one of the potential approaches for controlling shistosomiasis development and transmission. This depends on an in-depth understanding of the molecular interaction between schistosomes and snails (Zhang et al., 2008). Snails have potent internal defence systems and penetrating parasites are frequently eliminated (Van der Knaap \& Loker, 1990; Yoshino \& Vasta, 1990). To survive within their hosts, parasites have developed means to evade or 
interfere with snail internal defence responses. Digeneans can be used as tools to study snail immunobiology because of their diverse abilities to influence snail host internal defences. Biomphalaria glabrata responds to infection with Echinostoma paraensei by producing increased quantities of plasma polypeptides with the properties of lectins. Molluscan lectins are likely to mediate non-self recognition by binding and opsonizing foreign particles (Fryer et al., 1989; Richards\&Renwrantz, 1991).

So this study, aimed to firstly; differentiate between the two species of Biomphalaria using simple, cheap and modern tool of protein profile, rather than traditional and difficult morphology method or expensive PCR method. Secondly; comparative study to the response of both B.alexandrina and B.glabrata to Schistosma mansoni infection 7 and 14 days post exposure using total protein and protein profiles by SDSPAGE.

\section{Materials and methods}

\section{Biological Materials:}

Control and infected Biomphalaria alexandrina and glabrata snails were purchased from Theodor Bilharz Reseach Institute (TBRI), Egypt. Six identical groups $(5-7 \mathrm{~mm})$ of Biomphalaria spp (20 snails/ group).The first and the second one are control snails of both Biomphalaria alexandrina and glabrata respectively. The third and fourth groups, are B.alexandrina and glabrata 7 - days post exposure $(7$ PE.) to Schistosoma mansoni miracidia, while, the fifth and sixth groups are B.alexandrina and glabrata 14-days post exposure to S.mansoni miracidia(14 PE.) respectively. Snails from each group were transferred to clean aquaria with declorinated tap water. They were daily fed boi+led lettuce leaves. Dead snails were daily removed from the aquaria. The control and infected snail groups were collected after seven and fourteen days post exposure and kept at $4{ }^{\circ} \mathrm{C}$ until use.

\subsection{Protein assay:}

Protein contents measured by Bradford protein assay. Total protein concentration in tissue snail groups compared to a protein standard using spectrophotometer at $595 \mathrm{~nm}$ (Bradford, 1976).

2.3.Sodium dodecyl sulfate polyacrylamide gel electrophoresis (SDS-PAGE):

SDS-PAGE (12\% gel) analysis of control and infected snails tissue and their protein bands were carried out according to Laemmli (1970). Proteins were stained with $0.1 \%$ Coomassie Blue R-250 Silver. Broad range molecular weights marker (Promega, V8491) was run in parallel in order to calculate the molecular weights of proteins. Then, gel was photographed and the molecular weights were calculated using Molecular Imaging Software (MIS, Kodak).

\subsection{Similarity matrix:}

A similarity matrix was constructed on the basis of the presence / absence of bands from Dice's similarity coefficient (Dice, 1945) using the formula:

$\mathrm{S}=2 \mathrm{a} / 2 \mathrm{a}+\mathrm{b}+\mathrm{c}$

Where $\mathrm{a}=$ number of bands shared between samples 1 and 2, $\mathrm{b}=$ the number of bands present in 1 but not in 2 and $\mathrm{c}=$ number of bands present in 2 but not in one.

\subsection{Statistical methods:}

The independent t-test was used to distinguish the significant difference between snail groups on the means of total protein concentrations in uninfected (control) and infected snails.

\section{Results}

\section{Total protein contents:}

Figure (1) and Table (1) showed the total protein concentration of the tissue of control and infected B.alexandrina and B.glabrata snail groups. The total protein of B.alexandrina control group was $10 \mathrm{mg} / \mathrm{ml}$. While, total protein of B.glabrata control group was $3 \mathrm{mg} / \mathrm{ml}$. There was a significant decrease $(\mathrm{P}=0.003 \& 0.001)$ in total protein contents $(6 \& 4 \mathrm{mg} / \mathrm{ml})$ respectively in B.alexandrina after 7 days \& 14 days of exposure to S.mansoni miracidia (7 PE B.alexandrina. and $14 \mathrm{PE} \mathrm{B.alexandrina)} \mathrm{relative} \mathrm{to} \mathrm{control}$ one $(10 \mathrm{mg} / \mathrm{ml})$. While, there is a significant increase $(\mathrm{P}=$ $0.002)$ of total protein $(7.7 \mathrm{mg} / \mathrm{ml})$ in B.glabrata 7 days after exposure to S.mansoni (7 PE. B.glabrata) and insignificant increase $(\mathrm{P}=0.065)$ of total protein $(4.7 \mathrm{mg} / \mathrm{ml})$ in B.glabrata 7 days after exposure to S.mansoni (14 PE. B.glabrata) relative to control one $(3 \mathrm{mg} / \mathrm{ml})$.

Table (1): Total protein contents $(\mathrm{mg} / \mathrm{ml})$ of different groups of control and infected Biomphalaria snails. * Significant at $\mathbf{P} \leq \mathbf{0 . 0 5}$ :

\begin{tabular}{|l|l|}
\hline Snail groups & Total protein concentration $(\mathrm{mg} / \mathrm{ml})$ \\
\hline $\begin{array}{l}\text { Biomphalaria alexandrina control } \\
\text { (B.a.clt) }\end{array}$ & $10 \mathrm{mg} / \mathrm{ml} \pm 0.2$ \\
\hline $\begin{array}{l}\text { Biomphalaria glabrata control } \\
\text { (B.g.clt) }\end{array}$ & $3 \mathrm{mg} / \mathrm{ml} \pm 0.4^{*}$ \\
\hline $\begin{array}{l}\text { Biomphalaria alexandrina } 7 \text { days } \\
\text { postexposure (7 PE.) }\end{array}$ & $6 \mathrm{mg} / \mathrm{ml} \pm 0.1^{*}$ \\
\hline $\begin{array}{l}\text { Biomphalaria glabrata } 7 \text { days post } \\
\text { exposure (7 PE.) }\end{array}$ & $7.7 \mathrm{mg} / \mathrm{ml} \pm 0.14$ \\
\hline $\begin{array}{l}\text { Biomphalaria alexandrina } 14 \text { days } \\
\text { postexposure (14 PE.) }\end{array}$ & $4 \mathrm{mg} / \mathrm{ml} \pm 0.05^{*}$ \\
\hline $\begin{array}{l}\text { Biomphalaria glabrata } 14 \text { days post } \\
\text { exposure (14 PE.) }\end{array}$ & $4.7 \mathrm{mg} / \mathrm{ml} \pm 0.43$ \\
\hline
\end{tabular}

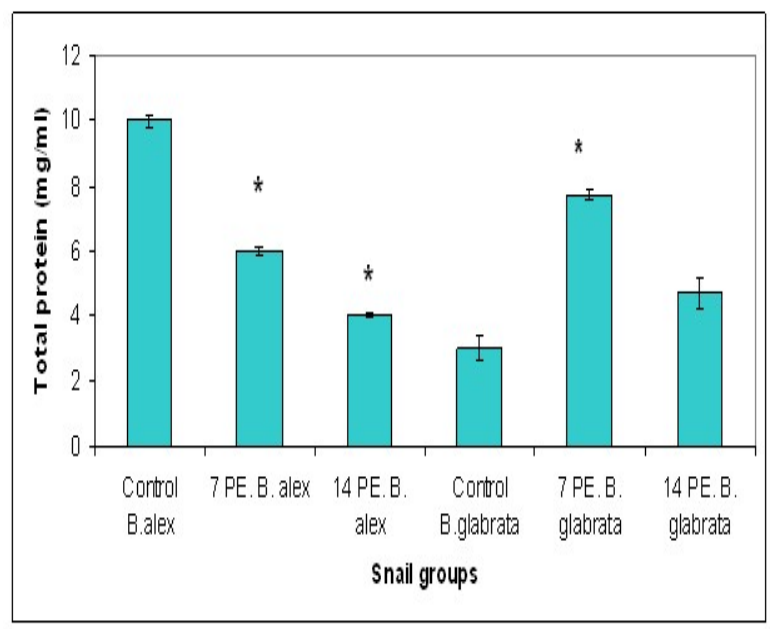

Figure (1); protein content $(\mathrm{mg} / \mathrm{ml})$ in Biomphalaria alexandrina control (control B.alex) and infected groups, 
control B.glabrata and infected groups $(7 \& 14$ days post exposure to S.mansoni. * Significant $\mathbf{P} \leq \mathbf{0 . 0 5}$.

\section{Protein profiles by SDS-PAGE:}

The protein profile pattern identified by SDS-PAGE electrophoresis for the infected and non-infected groups is shown in Table 2 and Figure 2. The results indicated that the protein profiles of different groups exhibited a complex pattern of polypeptides with a total number of 13 bands have molecular weights ranged from 15 to $300 \mathrm{KDa}$. The results also pointed out that the band with molecular weight of 25 $\mathrm{KDa}$ is the most common in all groups. $300 \mathrm{KDa}$ protein band is the specific band to B.alexandrina control (non-infected) snail. While 75 and $65 \mathrm{KDa}$ protein bands are specific bands to B.glabrata control (non-infected) snails. 275 and $150 \mathrm{KDa}$ protein bands are occasionally appeared in B.glabrata 14 days post-exposure (PE.) to S.mansoni miracidia. Whereas, low molecular weight protein bands of 35 and $15 \mathrm{KDa}$ appeared in both B.alexandrina and B.glabrata only at 7 days postexposure (7 PE.) to $S$.mansoni miracidia respectively.

Table (2): Protein profile of Biomphalaria alexandrina and B.glabrata control and infected snails.

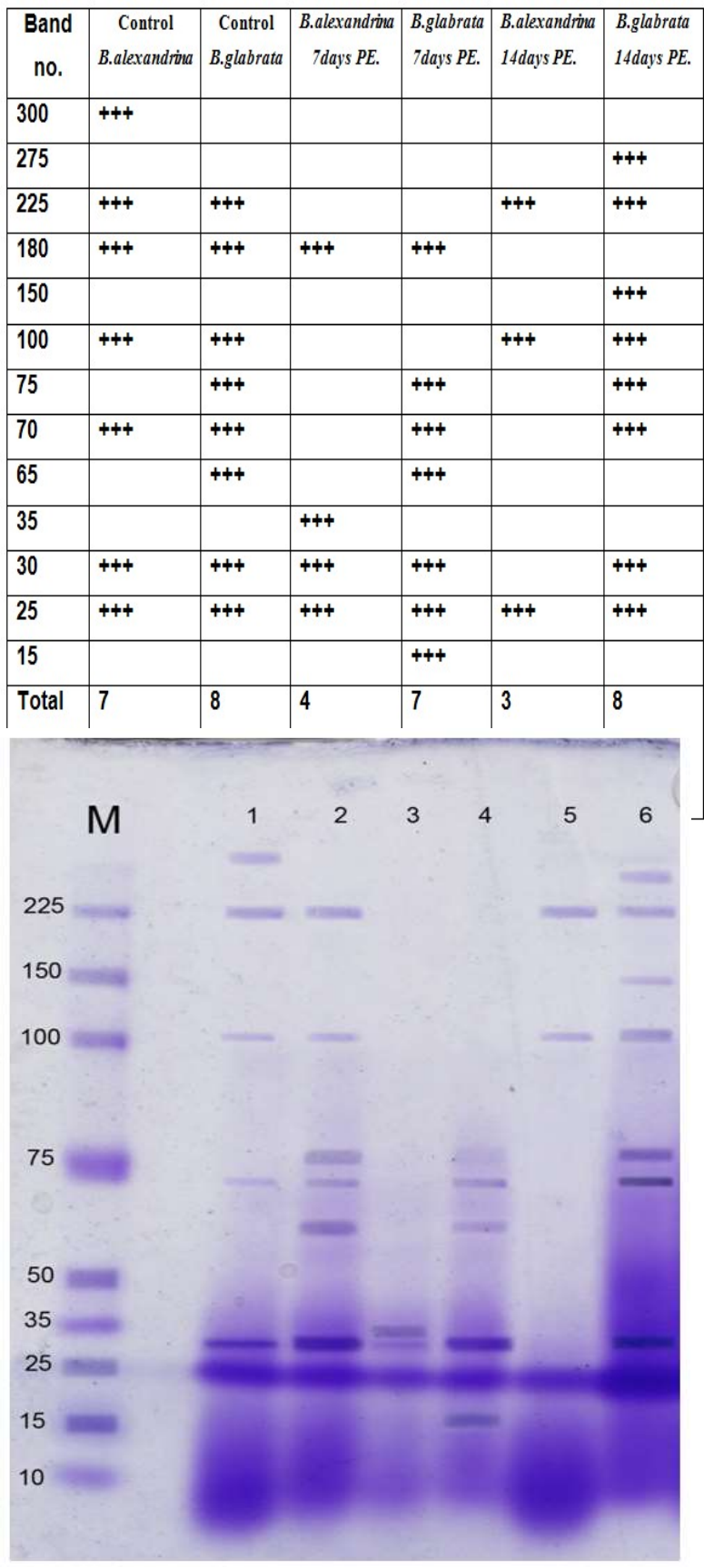

Figure (2): protein profile of snail groups. M: protein marker, lane 1: control B.alexandrina, lane 2: control B.glabrata, lane 3: 7 days Biomphalaria alexandrina post exposure to S.mansoni, lane 4: 14 days Biomphalaria alexandrina post exposure to S.mansoni, lane 5: 7 days Biomphalaria glabrata post exposure to S.mansoni, lane 6: 14 days Biomphalaria glabrata post exposure to S.mansoni.

\section{Similarity matrix:}

The similarity coefficient "S" based on the number of protein profiles separated by SDS-PAGE, shown in Table (3), revealed that there is a high similarity between the two noninfected snail species of which exhibited ' 0.8 'similarity. The similarities between control $B$. alexandrina group and its two exposed ones at $7 \& 14$ days $\mathrm{PE}$ are $0.5 \& 0.6$ respectively. The similarities between control B.glabrata group and its two exposed ones exhibited higher value $(\mathrm{S}=0.8 \& 0.75)$ than those of B.alexandrina.

Table (3): Similarity matrix of different electropherograms of protein subunits of different Biomphalaria groups:

\begin{tabular}{|c|c|c|c|c|c|c|}
\hline $\begin{array}{l}\text { Snail } \\
\text { groups }\end{array}$ & 1 & 2 & 3 & 4 & 5 & 6 \\
\hline 1 & 1 & & & & & \\
\hline 2 & 0.8 & 1 & & & & \\
\hline 3 & 0.5 & 0.5 & 1 & & & \\
\hline 4 & 0.57 & 0.8 & 0.5 & 1 & & \\
\hline 5 & 0.6 & 0.5 & 0.4 & 0.2 & 1 & \\
\hline 6 & 0.6 & 0.75 & 0.36 & 0.5 & 0.5 & 1 \\
\hline
\end{tabular}

\section{Discussion}

Preliminary observations on tissue polypeptide pattern indicated the differences between infected and control snails by both qualitative and quantitative techniques. The total protein contents of B.alexandrina generally decreased significantly as a result of infection. While, the total protein contents of B.glabrata increased due to infection compared with control group. Loker and Hertel (1987), revealed a significant increase in total protein in the plasma of B.glabrata infected for 4 and 8 days with Echinostoma paraensei. Previous studies on B.glabrata infected with Schistosoma mansoni indicated that after 11-14 days of infection, the plasma protein content of infected snails is significantly reduced (Lee and Cheng, 1972; Gress and Cheng, 1973; Michelson and Dubois, 1975; Stanislawski and Becker, 1979). So, those previous studies are tolerant with the present study of infected B.alexandrina. While, total protein of infected B.glabrata in the present study is coordinated with the results of Loker and Hertel (1987). Schistosoma mansoni therefore seems to evoke different response in different hosts as B.alexandrina or B.glabrata.

The electrophoretic pattern by SDS-PAGE revealed that, there were 13 different protein bands with molecular weights ranged from 15-300 KDa. Each group has a specific band, B.alexandrina has a specific band with $300 \mathrm{KDa}$, whereas, B.glabrata has a specific bands with molecular weights of 75 and $65 \mathrm{KDa}$. A band with molecular weight of $180 \mathrm{KDa}$ in the 
present study considered to be hemoglobin similar to that described previously by Loker and Hertel (1987). In contrary, Granath et al. (1987) described this band with molecular weight of $160 \mathrm{KDa}$. This band with $180 \mathrm{KDa}$ diffused completely in 14 days postexposure to parasite in both Biomphalaria species, this may be due to consumption of hemoglobin by parasite after prolonged exposure to S.mansoni. Uchikawa and Loker (1992), designed a group of molecules G1M (200 KDa) and G2M (80-120 KDa) as a response to infection with Echinostoma paraensei. But in the present study there were only two bands ( 275 and $150 \mathrm{KDa}$ ) appeared in B.glabrata after prolonged exposure (14 days) to parasite. A band with molecular weight of $65 \mathrm{KDa}$ appeared in both control and 7days PE. B.glabrata and disappeared in 14 days PE.

Adema et al. (1997 a \& b) demonstrated that $65 \mathrm{KDa}$ band appeared in infected B.glabrata, and this band was strongly bound by anti-fibrinogenes antibodies, comprised of at least two members of the fibrinogene related protein (FREPs) and responsible for the internal defence of the snail. Also FREPs have been identified by Stout et al. (2008). These apparent bands indicate the presence of immune polypeptides that bind to protein of S.mansoni miracidia and sporocyst and ensured by the study of previous authors who demonstrated that FREPs, G1M, and G2M may agglutinate different types of erthrocytes and other particulate materials or bind protein of echinostome miracidia and sporocyst both in vivo and in vitro (Hertel et al., 1994 and Locker et al., 1994). The 35 and 15 $\mathrm{KDa}$ protein bands of the present study appeared in B.alexandrina and B.glabrata only 7 days PE respectively.

According to similarity matrix in the present study, there is an obvious high similarity index $(\mathrm{S}=0.8)$ between the two species of Biomphalaria, despite of their morphological and molecular differences. Also higher values of similarity indices $(S=0.8 \&$ 0.75 ) obtained between all the groups of B.glabrata compared to control. However, moderate values of similarity $(\mathrm{S}=0.5 \&$ o.6) obtained between B.alexandrina groups compared to control. El- Dafrawy et al. (2006) demonstrated the highest similarity index 0.667 , in 2 weeks and 5 weeks post exposure to S.mansoni miracidia groups of B. alexandrina and the lowest one was in 3-days post exposure (0.5) compared to control group.

\section{References}

Adema, C.M.; Hertel, L.A.; and Loker, E.S. (1997a). Infection with Echinostoma parensei (Digenea) induces parasitereactive polypeptides in the hemolymph of the gastropod host B.glabrata. In Parasite effects on host physiology and Behavior (ed. N. Beckage), pp. 77-99. Chapman press, New York.

Adema, C.M.; Hertel, L.A.; Miller, R.D.; and Loker, E.S. (1997b). A family of fibrinogen related proteins that precipitates parasite derived molecules is produced by an invertebrate after infection. Proceeding of the National Academy of Science, USA 94: 8691-8696.

Bakry, F. (2009).Genetic varation between Biomphalaria alexandrina and Biomphalaria glabrata snails and their infection with Egyptian strain of Schistosoma mansoni. Journal of Applied Sciences Research, 5(9): 1142-1148.

Bradford, M. (1976) .A Rapid and Sensitive Method for the Quantitation of Microgram Quantities of Protein Utilizing the Principle of Protein-Dye Binding. Analytical Biochemistery 72:248-254.
Brown, S. D. (1994). Freshwater snails of Africa and their medical importance. Second edition. London: Taylor and Francis, 200.

Dice, L.R., 1945. Measures of the amount of ecological association between species. Ecology. 26: 247-302.

El-Dafrawy, S.M, El-Din, A.T, Hamid H.A. (2006). Electrophoretic patterns of protein fractionations in hemolymph and tissues of Biomphalaria alexandrina and Bulinus truncatus during course of schistosome infection. Journal of Egypt Society and Parasitology 36(3):795-807.

Fryer, S. E.; Hull, C. J.; and Bayne, C. J. (1989). Phagocytosis of yeast by $B$. glabrata carbohydrate specifity of hemocyte receptors and a plasma opsonin. Developmental and Comparative Immunology. 13: 9-16.

Granath, W.O.; Spray, F. J., and Judd, R. C. (1987). Analysis of B.glabrata (Gastropoda) hemolymph by sodium dodecyl sulphate polyacrylamide gel electrophoresis, high performance liquid chromatography and immunoblotting. Journal of Invertebrate Patholology. 49(2): 198-208.

Gress,F.M., and Cheng, T. C. (1973). Alteration in total serum proteins and protein fractions in Biomphalaria glabrata parasitized by Schistosoma mansoni. Journal of Invertebrate Patholology. 22: 382-390.

Hertel, L. A.; Stricker, S. A.; Monroy, F. P.; Wilson, W. D.; and Loker, E. S. (1994). B.glabrata hemolymph lectins: binding to bacteria, mammalian erythrocytes, and to sporocysts and rediae of Echinostoma paraensei. Journal of Invertebrate Patholology. 64: 52-61.

Hickman, C. P. (2000). Mollusca. In Animal Diversity (2nd edn), p. 448, McGraw Hill.

Laemmli, U. K. (1970). Cleavage of structural proteins during the assembly of the head of bacteriophage T4. Nature, 227:680-685.

Lee, F. O., and Cheng, T. C. (1972). Schistosoma mansoni: Alteration in total protein and hemoglobin in the hemollymph of infected Biomphalaria glabrata. Experimental Parasitology 31: 203-216.

Loker, E. S., and Hertel, L. A. (1987). Alteration in B.glabrata plasma induced by infection with the digenetic trematode Echinostoma paraensei. Journal of Parasitology.73(3):503513.

Loker, E. S.; Couch, L.; and Hertel, L. A. (1994). Elevated agglutination titres in plasma of B.glabrata exposed to Echinostoma paraensei: characterization and functional relevance of a trematode-induced response. Parasitology 108: $17-26$.

Lotfy. W. H; Dejong. R. J.; Black, B. S.; and Loker, E. S. (2005).Specific identification of Egyptian Biomphalaria species and possible hybrids using the polymerase chain reaction based on nuclear and mitochondorial loci. Molecular and Cellular Probes.19: 21-25.

Malek, E. A. (1985). Snail hosts of schistosomiasis and other snail transmitted disease in tropical America: a manual. Pan 
American Health Organziation Scientific Publication No. 478.

PAHO, Washington.

Michelson, E. H., and Dubois, L. (1975). Intraspecific variations in the hemolymph of Biomphalaria glabrata, a snail host of Schistosoma mansoni. Malacologia 15: 105-111.

Richard, E. H., and Renwrantz, L. R., (1991). Two lectins on the surface of Helix pomatia hemocytes: a $\mathrm{Ca}++$-dependent, Gal Nac-specific lectin and a $\mathrm{Ca}++-$ independent, mannose 6phosphate specific lectin which recognizes activated homologous opsonins. Journal of Comparative Physiology. B 161: 43-54.

Stanislawski, E., and Becker, W. (1979).Influences of semisynthetic diets, starvation and infection with Schistosoma mansoni (Trematoda) on the metabolism of Biomphalaria glabrata (Gastropoda). Comparative Biochemistery and Physiology. 63 A: 527-533.

Stout, B.; Adema, C.M.; Zhang, S.M, and Lokers E.S. (2008).The biology of FREPs:diversifled lectins with fibrinogen related domains from the freshwater snail B.glabrata. In: Vasta GR, Ahmed H. (eds) Animal lectins: A functional view. Cleveland, OH: CRC Press Taylor\&Francis; In Press.

Sturrock, R.F. (2001).Schistosomiasis epidemiology and control: how did we get

here and where should we go?. Mem. Inst. Oswaldo Cruz 96 (Suppl.), pp.17-27.

Uchikawa, R., and Loker, E. S. (1992). Echinostoma paraense $i$ and $S$. mansoni-adherence of unaltered or modified latex beads to hemocytes of the host snail B. glabrata. Expermintal Parasitology 75: 223-232.

Van der Knaap, W.P.W. and Loker, E.S. (1990). Immune mechanisms in trematode snail interactions. Parasitology Today 6: 175-182.

Yoshino, T.P. and Vasta, G. R. (1990). Parasite-invertebratee host immune interactions. In Advances in Comparative and Environmental Physiology, Vol.24 (Ed. Vasta, G.R.), pp.125167. Springer Verlag, Berlin.

Yousif, F.; Haroun. N.; Ibrahim A., and El-Bardicy, S., (1996). Biomphalaria glabrata: a new threat for schistomiasis transmission in Egypt. Journal of Egypt Society and Parasitology 26: 191-205.

Zhang, S. M; Zeng ,Y., and Loker ,E. S. (2008).Expression profiling and binding properties of fibrinogen- related proteins (FREPs), plasma proteins from the schistosome snail host B.glabrata. Innate Immunity 14(3): 175-189. 


\section{الملخص العربي}

"ألاختلافات النوعيه بين قوقع بيومفلاريا الكسندرينا و بيومفلاريا جلابراتا في وجود و غياب البلهارسيا المعويه باستخدام تحليل البروتين."

تعتبر البلهارسيا من أكثر الامر اض الثائعه في مصر منذ قديم الاذل. و قد تم التعرف علي نوعين من القواقع هما بيومفلاريا الكسندرينا و بيومفلاريا جلابر اتاو التي تعتبر من انجح العوائل الوسيطه في مصر. في هذة الدراسه تم قياس كلا من البروتين

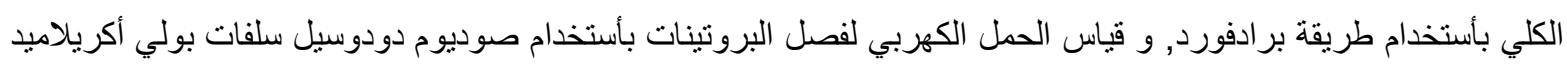

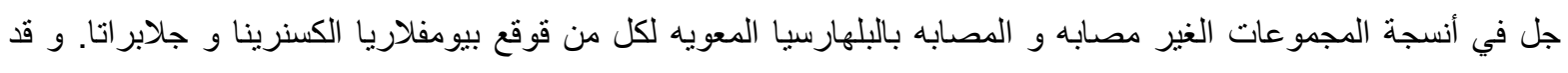

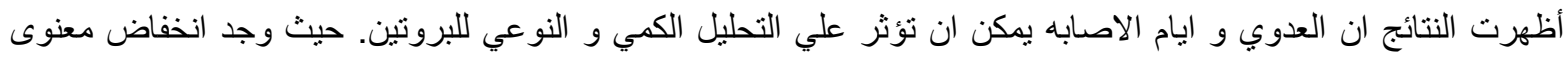

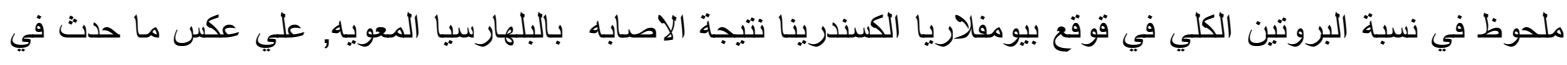

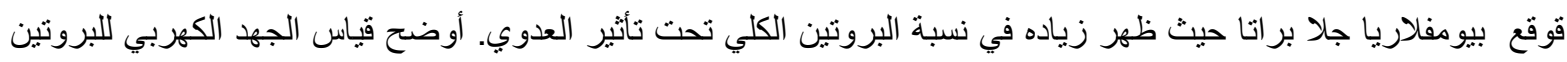

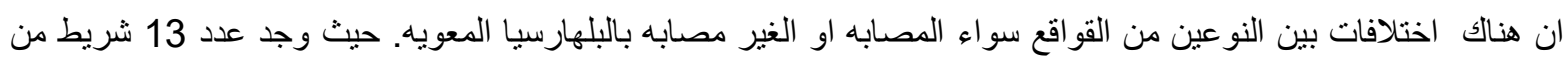

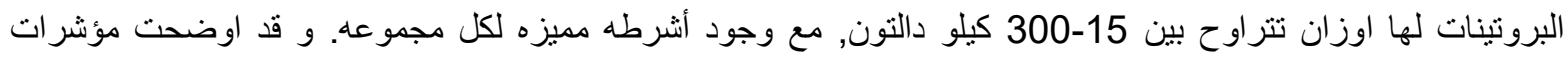
التشابه ان اعلي نسبة تشابه0.8 هي بين مجمو عات بيومفلاريا الكسندرينا و بيو مفلاريا جلابر اتا الغير مصابه. تعتبر هذه الدراسه هي محاوله لتعريف الانواع المتثابهه من الحيو انات باستخدام تقنيات حديثه و بسيطه بدلا من الطرق القديمه التي تعتمد علي الثنكل الظاهري فقط. و ايضا اكتشفت الدراسه تنوع في اثرطة البروتين نتيجة الاصابه بالبلهارسيا المعويه. 